\title{
RILLAND GULLY EROSION RISK OF LATERITIC TERRAIN IN SOUTH-WESTERN BIRBHUM DISTRICT, WEST BENGAL, INDIA
}

\section{Risco a erosão em ravinas e voçorocas nos terrenos lateríticos de South-Western Birbhum District, West Bengal, India}

V. C. Jha

Professor and Head, Department of Geography Visva-Bharati University, Santiniketan - 731235

West Bengal, India vcjha@asia.com

S. Kapat

Project Scientist, DST, W. B., R \& D Project, Department of Geography Visva-Bharati University, Santiniketan - 731235 West Bengal, India

Artigo recebido para publicação em 19/05/09 e aceito para publicação em 14/07/09

ABSTRACT: It is a known fact that no part of the earth surface is free from threat.It applies to Birbhum District, West Bengal, Indian Lateritic Terrain also. The existing terrain is characterized by mainly climatogenetic processes. Though the impact of climate change is vital in the shaping of the lesser topographies in the study-area. The study-area is characterized by micro landforms e. g. rills, gullies, water falls, terraces, gorges type features and limestone topographic type features. The denudational processes are very significant in the area in general but the differential erosion is evident in particular. It resembles the topographies with the African and the Brazillian Highlands. This paper interprets the rill and gully erosion risk in the lateritic terrain and their consequences in regional sustainable development and environmental management

Keywords: Rill Erosion. Gully Erosion. Erosion Risk. Lateritic Terrain. Remote Sensing and Action Plan.

RESUMO: $\quad$ É fato conhecido que nenhuma parte da superfície da Terra é livre de problemas. Isto implica também as Terras Lateríticas Indianas do Distrito de Birbhum, Oeste de Bengala. Estas terras são caracterizadas principalmente por processos morfogenéticos. As mudanças climáticas geraram impactos importantes no modelado do relevo da área de estudo. A área de estudo é caracterizada por micro-formas de relevo, por exemplo feições do tipo ravinas, voçorocas, cachoeiras, terraços, gargantas e feições topográficas típicas de relevos calcários. Estes processos denudacionais são muito significantes na área em geral, mas a erosão diferencial é evidente em particular. São semeIhantes a topografias com áreas altas da África e do Brasil. Este artigo interpreta os riscos a erosão em ravinas e voçorocas em terrenos lateríticos e suas conseqüencias no desenvolvimento sustentável regional e no gerenciamento ambiental.

Palavras-chaves: Ravinas. Voçorocas. Riscos a erosão. Terrenos lateríticos. Sensoriamento Remoto. Plano de Ação. 


\section{INTRODUCTION}

In response to today's worldwide issues of land degradation and its sustainability, multi disciplinery geomorphic perceptions of river catchment or watersheds with remote sensing techniques and also with non cyclic dynamic equilibrium concept are being recognized in wider extent. In India, increasing population growth, worsening plight of the poor, low landman ratio, urbanization with the quest for immediate gains to meet the growing demands are responsible for degraded landscape ecology as noted in India. Degraded lands account for about 2 billion ha(15\%) $n$ the world, 39.0\% in Asia, and about 9.4\% in India. Degraded lands in India covers about 187.7 million ha or $57.1 \%$ of its total area (Chandra, 2006). Moreover economic development are still often found to be done at their environmental cost or not to be matched up to expectations.

Lateritic soilscapes are ecologically fragile because of its inherent constraints of acidity, nutrient loss, chemical impairment, crusting, water erosion and poor water holding capacity as these are highly weathered and leached soil and enriched with ox ides of iron and aluminum in tropics(Jha.et.al,2008). Therefore, their recognitions, spatial distribution, degradation status and management at basin or catchment or watershed level are vital not only to restore already degraded lateritic terrain but also to prevent their further degradation. The drainage basin or watershed is actually an ideal geomorphic unit for effective land - water resource management, controlling runoff and sediment yield, enhancing ground water storage, mitigation of erosion hazards or other natural disaster and its overall sustainable development. Hence drainage basin oriented applied geomorphic apprehension is essentially requisite for effective watershed planning and management.

Since the period of post 1955,basin or catchment or watershed oriented geomorphic studies focus vigorously on morphometric characterization ,inventories of land form assemblages, land-water resources ,quantification of run off, sediment yield, and rill-gullyriver erosion- hazards, identification of hydrogeomorphic units ,erosion prone sites or other degraded localities in different matrix of landscape components and periodic updating of their priority status for effective eco friendly and economically viable land management with immense uses of remote sensing data. Horton was the pioneer of the basin morphometry $(1932,1945)$. This quantitative approach with modifications was later developed by Strahler (1950, 1952, 1956, 1957, 1964), Millar (1953), Schumm (1956,1957), Moriswa (1957, 1959), Coates (1958), King (1967), Verma (1969), Chorley (1969), Mueller (1968), Kar \& Bando-padhaya (1974), Singh (1974, 1967, 1978), Sharma (1968, 1979, 1982), Misra et al (1984), Chakraborty (1991), Kale.et al. (1994), Sing (1995), Chaudhury and Sharma (1998), Murthy (2000), Saxena et al. (2000), Durbude et al (2001), Singh \&Dubey (1998, 2002), Nookaratnam et al (2005), Jha (1996, 2000, 2003, 2005, 2008) and other.

\section{OBJECTIVES}

In the context of above point of views, the present study aims at determining rill and gully erosion risk of drainage basins in lateritic landscape. Objectives are:

- drainage basin and its lateritic confinement wise morphometric characterizations to infer erosion intensity;

- determination of risk of rill and gully erosion hazards in terms of their kind, extent and degree as manifested in morphology and morphometric characteristic of geomorphic features in hydrogeomorphic units and land-use practices within lateritc confinement of the basins;

- rill - gully erosion risk based classification of drainage basins;

- geomorphic prioritization with preparation of action plan.

\section{DATA BASE AND METHODOLOGY}

Integrated approach has been adopted by using Precision geocoded P6 and LISS III on 1:50000, December 2006, Toposheets of 73M and 73P series on 1:50,000 (SOI), daily, monthly and annual rainfall data for the period of 10 years ( basin wise rainfall are computed form isohyte maps of the study area as these 
data are available for only 7 sub substations), Census map \& data 2001, Cadastral map, Soil map of NBSS \&LUP, Geological map (GSI) and field data of pre and post monsoon period.

Visual interpretation of satellite imageries along with the said collateral materials have been applied for the identification and delineation of sample of basins with varying extent of lateritic exposure and rill-gully networks, land uses .Here lateritic exposure itself is one of the hydrogeomorphic units. 45 sub catchments(42 III order sub-basins and 3 II order sub-basins) of tributary basins of two main river systems(the Ajay.R\&the Mauyrakshi.R) of the study area have been taken into consideration. Morphometric analysis of linear areal and relief of each entire sample basin and its lateritic exposures have been done on the basis of satellite imageries, toposheets and field data. Sample basins are divided in to grids of $1 \mathrm{Km}^{2}$ and rill-gully affected lateritic patches into grids of $100 \mathrm{~m}^{2}$ in this regard $100 \mathrm{~m}^{2}$ grids have been chosen to have better morphometric reading from field. Fournier index is also used as an erosion index. In addition to it, soil loss t/ha by universal soil loss (USLE) has been estimated in different non arable land use/cover (TAB. 1). Various thematic maps according to the obtained values of morphometric attributes, annual erosion loss, adverse land use of rill gully affected lateric terrain as obtained from satellite imageries and field. All these maps of rill gully erosion risk parameters are rated and integrated to generate map of rill and gully erosion risk based classified basins with their priority status.

TABLE 1. Techniques used

\begin{tabular}{|c|c|c|}
\hline Techniques used & Derivations & Postulator \\
\hline Relative relief & $\begin{array}{l}\text { Difference between minimum and maximum height of a } \\
\text { unit area or grid }\end{array}$ & Smith(1935) \\
\hline Dissection Index & Relative relief/Absolute relief per unit area or grid & Dovnir(1957) \\
\hline Average slope(\%) & $\begin{array}{l}\text { Slope in \%- x/yX100;x-vertical drop between successive contours, } \\
\text { y-Horizontal distance on respective scale }\end{array}$ & \\
\hline Drainage frequency of a basin & $\begin{array}{l}\text { “Nu/Au Nu-total number of stream segments of all order } \\
\mathrm{Au}-\mathrm{Basin} \text { area }\end{array}$ & Horton(1932) \\
\hline Drainage density of a basin & $\begin{array}{l}\text { "Lu/Au Lu-total length of stream segments cumulated for each } \\
\text { stream order Au-Basin area }\end{array}$ & Horton(1932) \\
\hline Elongation ratio & $\begin{array}{l}\text { d/Lb, d-diameter of the circle of the same area as basin, } \\
\text { Lb-maximum basin length }\end{array}$ & Schumm(1956) \\
\hline Relief ratio & H/Lb, H-Total height, Lb-maximum basin length & \\
\hline Fournier index & $\begin{array}{l}\mathrm{p}^{2} / \mathrm{P}, \mathrm{P} \text { mean annual rainfall-mm, } \mathrm{p}^{2} \text {-highest mean monthly } \\
\text { rainfall-mm }\end{array}$ & \\
\hline Universal soil loss equation & $\begin{array}{l}\text { A=RKLSCP where A-Average annual soil loss (t/h/y, R-rainfall } \\
\text { erosivity, K-Soil erodibility, LS-Slope, CP-existing cropping and } \\
\text { conservation practice }\end{array}$ & $\begin{array}{l}\text { Wischmeire and } \\
\text { Smith(1978) }\end{array}$ \\
\hline $\begin{array}{l}\text { Visual interpretation } \\
\text { and field survey }\end{array}$ & $\begin{array}{l}\text { Visual interpretation of Precision geocoded P6 and LISS III } \\
\text { on 1:50000 Satellite and field survey on the basis of observation } \\
\text { points as obtained from satellite imageries. } \\
\text { Surveying instruments also-used }\end{array}$ & \\
\hline
\end{tabular}




\section{STUDY AREA}

Study area lying between $23^{\circ} 04^{\prime} 27^{\prime \prime} \mathrm{N}$ and $24^{\circ} 07^{\prime} 47^{\prime \prime} \mathrm{N}$; 87 $7^{\circ} 05^{\prime} 28^{\prime \prime} \mathrm{E}$ and $87^{\circ} 50^{\prime} 30^{\prime \prime} \mathrm{E}$ forms a part of the lower Ganga, referred to as the self of lateritic alluvium locally known as Rahr Bengal (Spate, 1967); Biswas (p.158, 2002); Jha (p.20, 2005). It is bounded by Bardhaman Murshidabad districts and Jharkhand in the south, the north, the east and west respectively. Administratively it is comprised of 7 CD blocks and 1167 villages under 10 police stations of Suri and Bolpur Sub divisions (FIG. 2). The area with mean annual temperature $26^{\circ} \mathrm{C}$ and mean annual rainfall $1462.73 \mathrm{~mm}$ is characterized by sub humid tropical/monsoon climate. The said area is composed of the following geological formations: 1. Recent Alluvium (Kandi Formation), 2. Older Alluvim(Rampurhat Formation), 3. Literate (Pliocene-Pliestocene), 4. Rajmahal Trap (Jurassic to Cretaceous), 5. Gondwana Super (Dubrajpur, Ranigang, Barren measure and Barakar formations) and 6. Archaean-proterozoic. Alluvial plain in the east and erosional plain with a few hillocks in the west constitute its major physiography. The general elevation varies between $34 \mathrm{~m}$ and $157 \mathrm{~m}$. Altitude between $40 \mathrm{~m}$ and $80 \mathrm{~m}$ occupies most of the area. Most of the rill and gully affected lateritic exposures are profound in this altitudinal zone. Altitude higher than $120 \mathrm{~m}$ is only confined to the western fringe of Rajnagar and Khorasol Blocks having insignificant lateritc exposures. The rivers - Ajay, the Mayurakshi and their tributaries drain the area with general slope from west to south-east. Laterite - latirtic soil, alluvium (older and younger) and red soils of varying texture are found in the area. Natural vegetation like Sal (Shorea robusta), Palash (Butea monosperma), Arjun (Terminalia arjuna), Sonajhuri, Eucalyptus, Mango, Bamboo etc. commonly grow here.

The study area has considerable constraints of rill-gully erosion specially in exposed lateritic patches as noticed intesely in the Ajay-Maurakshi interfluves 45 sample sub basins or micro watersheds of the Kopai, Bakreswar and Dwaraka basins (Tributaries of the Mayurakshi. R) and the Hingla basin (Tributary of the Ajay River.).

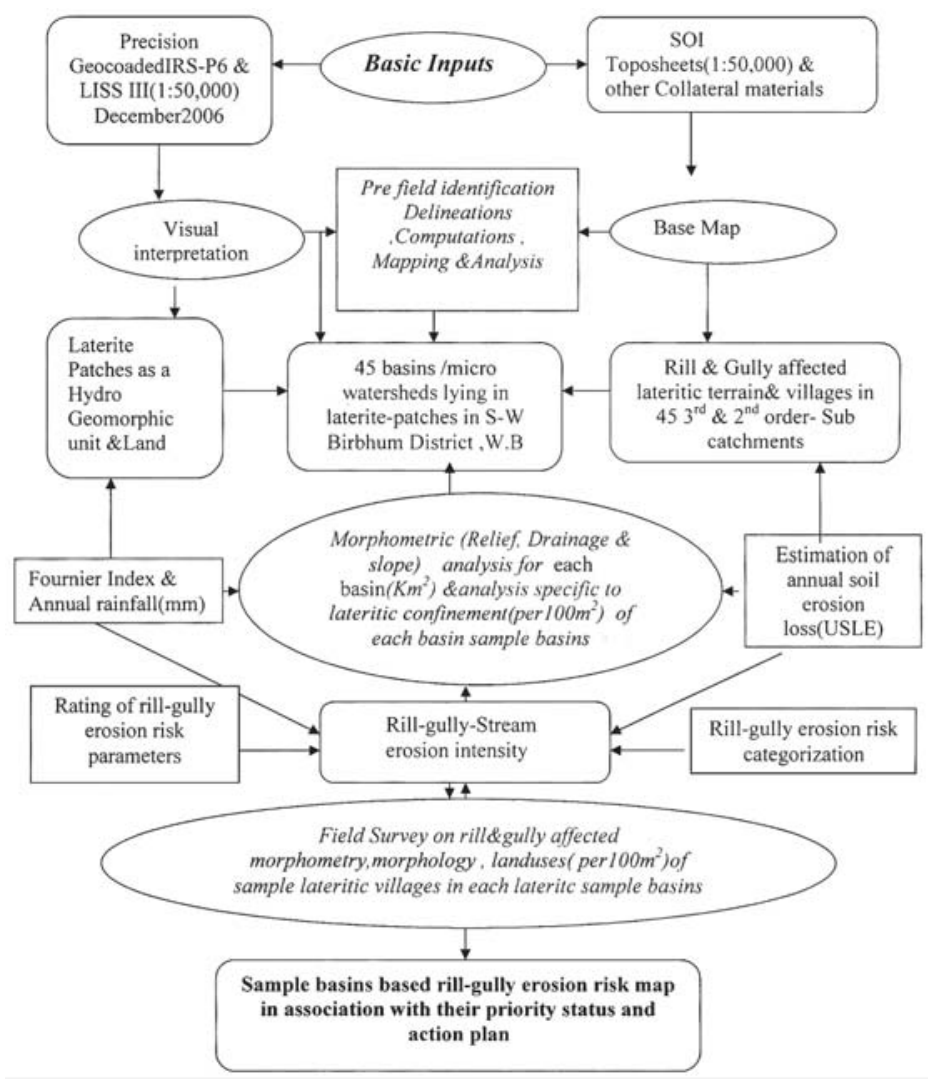

FIGURE 1. Methodological approach. 


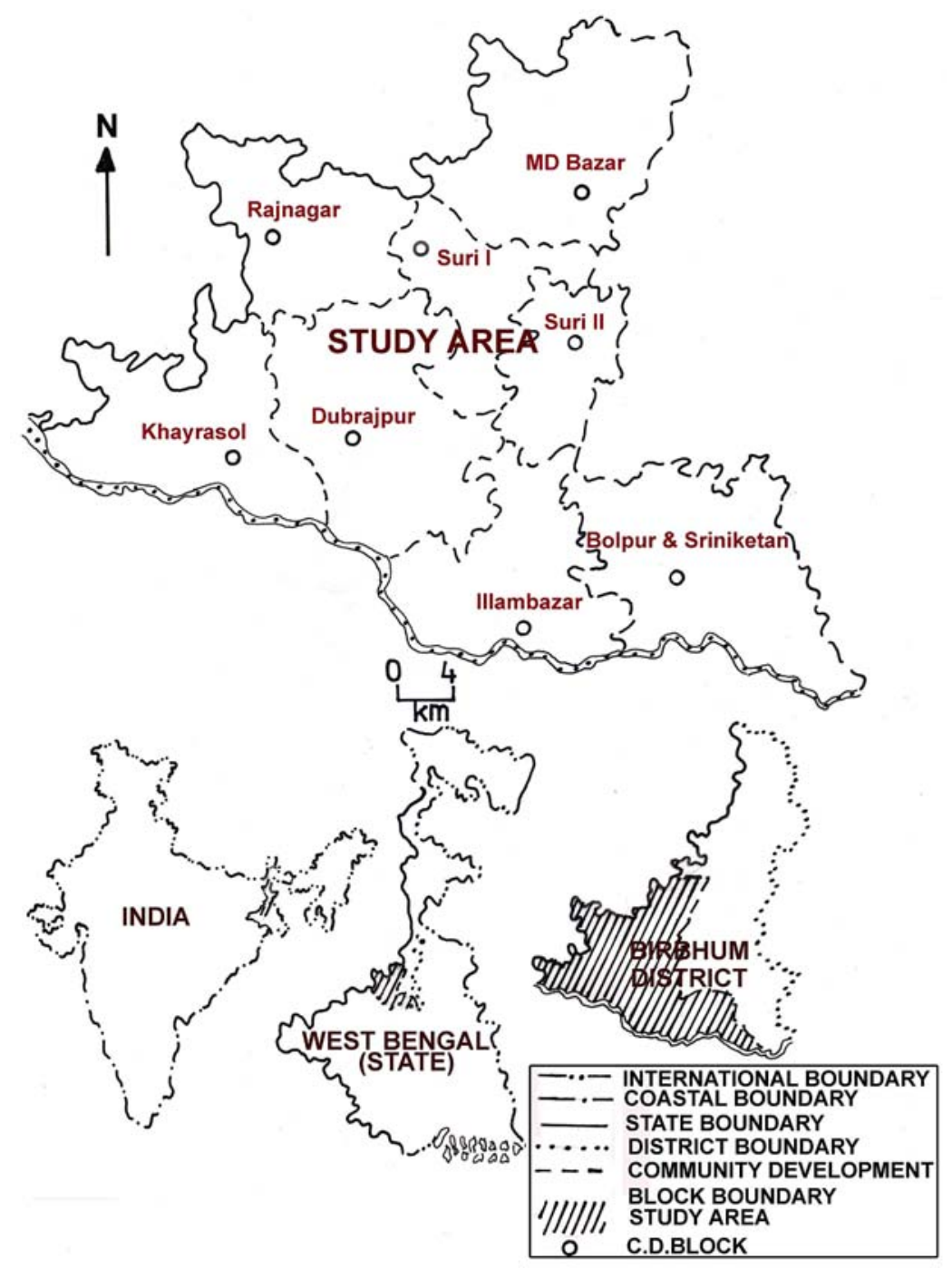

FIGURE 2. Location of Study area.

\section{RESULTS AND ANALYSIS}

The study area belonging to the Rahr Bengal have significant extent of lateritic landscape degraded by varying combinations of rill, gully \& stream network. Lateritic exposures affected by rills and gully erosion are very distinct in the eastern part of the study area particularly in the central Bolpur-Sriniketan, south eastern Illambazar, eastern Dubrajpur, western Suri-I and southern-eastern MD bazar blocks (TAB. 2). These are mainly observed in the 3 rd and 2nd order sub basins of the Kopai. N, Bakreswar N, Kuskarani .N, Dwaraka $\mathrm{N}$ and other few very small sub basins of the Ajay \& the Mauyrakshi Rivers (TAB. 2 \& FIG. 3).
On the contrary, lateritic exposures are small and scattered in nature and mostly subjected to rill erosion along with small or insignificant gullies in the remaining part of the study area (TAB. 3). In respose to the extent of lateritic exoposures, 18 sample basins out of the total sample basins (45) are efficacious in rill and gully erosion whereas remaining 27 sample basins are mainly subjected to rill erosion as noted in satellite imageries and field survey (FIG. 9). Their propensity is high in non arable lands like protected and reserve forests, mining waste, barren terrain and also marginal agri-cultural plots. The basin 1 possesses maximum num-ber of villages (16). Maximum lateritic villages (7) is noted in the basin-33. 


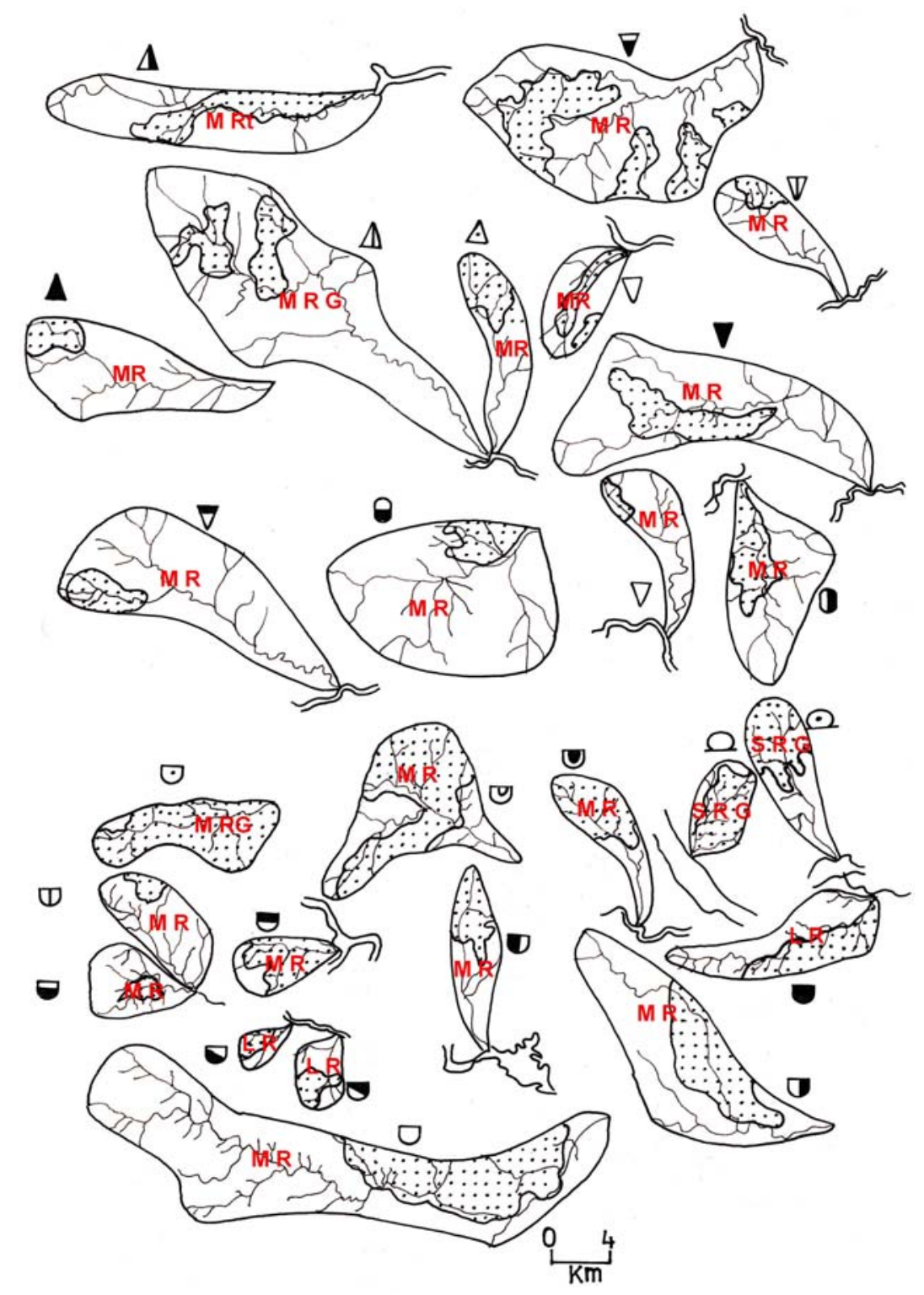

FIGURE 3. Locations of sample drainage basins on the Lateritic Terrain.

\subsection{Characteristics of sample basin subjected to rill and gully erosion}

Vulnerable rills and gullies are observed in four very small basins $3-6\left(1.46 \mathrm{~km}^{2}-1.76 \mathrm{~km}^{2}\right)$ in the lateritic right bank of the kopai adjacent the south main kopai canal (FIG $12 \& 13$ ). These basins have $100.0 \%$ lateritic coverage, high annual soil loss (24.13 t/ha$28.23 \mathrm{t} / \mathrm{ha}$ ), spectacular dimension of terrain deformation and degraded land (69.86\%-74.03\% ) inspite of having low relative relief $\left(1.78 / 100 \mathrm{~m}^{2}-2.09 /\right.$ $\left.100 \mathrm{~m}^{2}\right)$, dissection index $\left(0.02 / 100 \mathrm{~m}^{2}-.029 / \mathrm{m}^{2}\right)$, very low relief ratio (0.01-0.025), coarse 1st order drainage characteristics (drainage density and frequency (2.7$6.16 / \mathrm{km}^{2} ; 2.0-211 \mathrm{~km} / \mathrm{km}^{2}$ ) and considerable forest cover on average (TAB. 2,4 \& FIG 4 -8). Their higher erosive potential are actually lead by the higher mean annual rainfall (1521.37mm-1529.4mm), Fournier index (around 99.0) level or very gentle lateritic plain with average slope of $1.72 \%-2.13 \%$, impermeable heavy clay loam texture with high erodibility (0.35-.0.45), Weighted mean of bifurcation ratio (3-4.52) drainage 
frequencies of rill-gully-stream segments $\left(3.11 / 100 \mathrm{~m}^{2}\right.$ $4.31 / 100 \mathrm{~m}^{2}$ ), existence of the kopai main south canal, degraded forest $\left(0.20-0.41 \mathrm{~km}^{2}\right)$ and rapid transformation of land (57.74\%). Spectacular and largest gully formation is found in the basin 4 where the south Kopai main canal traverses Ballavpur lateritic patch producing more runoff and sediment yield potential as indicated by the above said magnitudes of parameters including elongation ratio with value of 0.92 higher than other three basins (TAB. 2, 4 \& 6). There is also evidences of temporal change in these gully networks as suggested by TAB. 6 . These changes actually follow seasonal rainfall effectiveness (Plate $1 \& 2$ ).

Similarly sample basins $12-14$ \&18 in the Bakreswar catchment in Dubrajpur block across the annual rainfall regime of $1500 \mathrm{~mm}$ also have appreciable effectiveness of rill and gully inspite of their low mag- nitudes of relief morphometry as depicted in TAB. 4.They acquire lateritic surface ranging between $63.14 \%$ $\& 100.0 \%$. They are quite different from those in the kopai catchment having relatively less terrain deformations. They coincide with the higher Fournier index (99.17-101.0), moderate mean annual rainfall between (1392.12mm-1410.32mm), moderate weighted mean of bifurcation ratio (2-4.37) moderately fine rill-gully stream frequency $\left(2.92 / \mathrm{km}^{2}-6.38 / \mathrm{km}^{2} ; 2.73 / 100 \mathrm{~m}^{2}-\right.$ $3.17 / 100 \mathrm{~m}^{2} \&$; 1 st order $2.23 / \mathrm{km}^{2}-4.2 / \mathrm{km}^{2}$ ), drainage -rill-gully -stream density (coarse-0.87), mean annual soil loss t/ha (15.05-25.07) with high erodibility of clay $2.09 \mathrm{~km} / \mathrm{km}^{2}-2.83 \mathrm{~km} / \mathrm{km}^{2}$; moderate $1.2 \mathrm{~m} / 100 \mathrm{~m}^{2}$ $\left.1.53 \mathrm{~m} / 100 \mathrm{~m}^{2}\right)$, elongation ratio $(0.70-0.84)$, clay soil texture (0.27-0.45), affected area (24.39\%-57.85\%). So Significant extent of laterite along with all the said magnitudes make these basins quite prone to the rill and gully erosion.

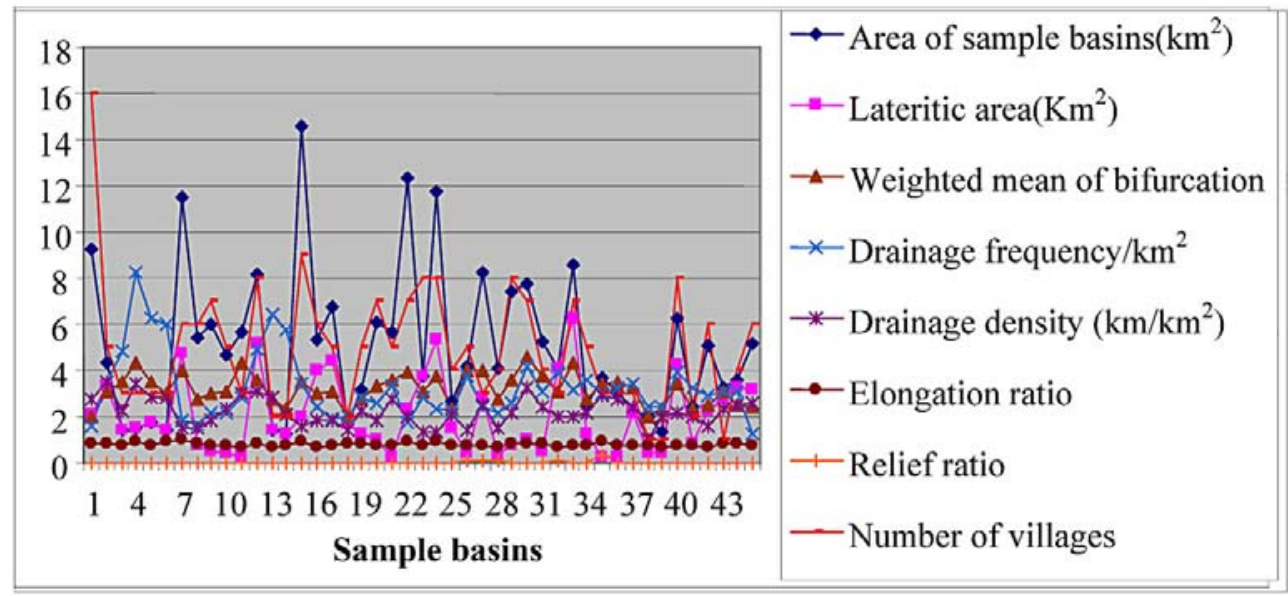

FIGURE 4. Morphometric Characteriscs of Sample Basins with their Varying Extent of Lateritic Exposures.

Anthro geomorphic alterations by forest blank for commercial morumm extraction (basin 13 in Bodakuri village), and china clay mining (basin 14 in Chandidaspur village) and Bakreswar reservoir, thermal power generation and canal (basin-18) help them to attain the higher magnitude of lateritic landscape components accelerating their inherent dynamism.

In contrast, Basins 2, 43 \& 44 (microwatersheds of the Ajay catchment in Chawpahari Jungle Illambazar block and Maurakshi river in Charicha forest and surrounding-Md bazar block) does not have rugged badland topography inspite of having appreciable spectacular lateritic extent (77.41\%-89.50\% ), moderate to the higher erodibilty of clay soil texture (0.27-0.45), mean annual rainfall $(1469.43 \mathrm{~mm}-1528.69 \mathrm{~mm})$, rainfall aggressiveness (99.60-100.21) and drainage-rill-gullystream frequency $\left(3.06 / \mathrm{Km}^{2}-3.53 / \mathrm{Km}^{2} ; 3.0 / 100 \mathrm{~m}^{2}\right.$ $\left.4 / 100 \mathrm{~m}^{2} ; 1.84 / \mathrm{Km}^{2}-3.2 / \mathrm{Km}^{2}\right)$, drainage density (2.27 $\mathrm{km} / \mathrm{Km}^{2}-2.54 \mathrm{~km} / \mathrm{Km}^{2} ; 1.34 \mathrm{~m} / 100 \mathrm{~m}^{2}-3 \mathrm{~m} / 100 \mathrm{~m}^{2}$ ), elongation ratio (0.78-0.83), annual soil loss (24.78$26.19 \mathrm{ha} / \mathrm{t})$ rill-gully affected area (20.27\%-48.61\%) on average. This difference results from wider extent of forest, good vegetation effectiveness with restricted 
runoff yield and erosive potential and relatively less human intervention. The remaining basins $(1,15,20$, 24, 32 \&41) acquire smaller extent of rills and gullies (Mean depth less than $1.5 \mathrm{~m}$, width $2.36 \mathrm{~m}$, average slope $2.84 \%$,). Basin 1,15,20,24,32 and41 have moderately limited rills and gullies.

In the study area four types of gullies are identified such as very shallow (less than $1.5 \mathrm{~m}$ ), shallow $(1.5 \mathrm{~m} 3.0 \mathrm{~m})$ and moderately deep $(3.0 \mathrm{~m}-4.5 \mathrm{~m})$ and deep $(>4.5 \mathrm{~m})$ gullies. All these types are distincty found in Bolpur-Sriniketan block. On the contrary other sample basins represent shallow and moderately deep gullies.

Hence foregoing discussion makes it clear that there are variation ins erosive potential in accordance with the extent of laterite exposure along with the integrated effectiveness of magnitudes of drainage attributes, soil loss, vegetation and adverse land use caused by local people and government polices (FIG 12). Moreover man induced modified lateritic basins with moderately fine $1^{\text {st }}$ order and over all drainage frequency produce more sediment yield (FIG. 4, 5, 6, 7, 8 \& 12).

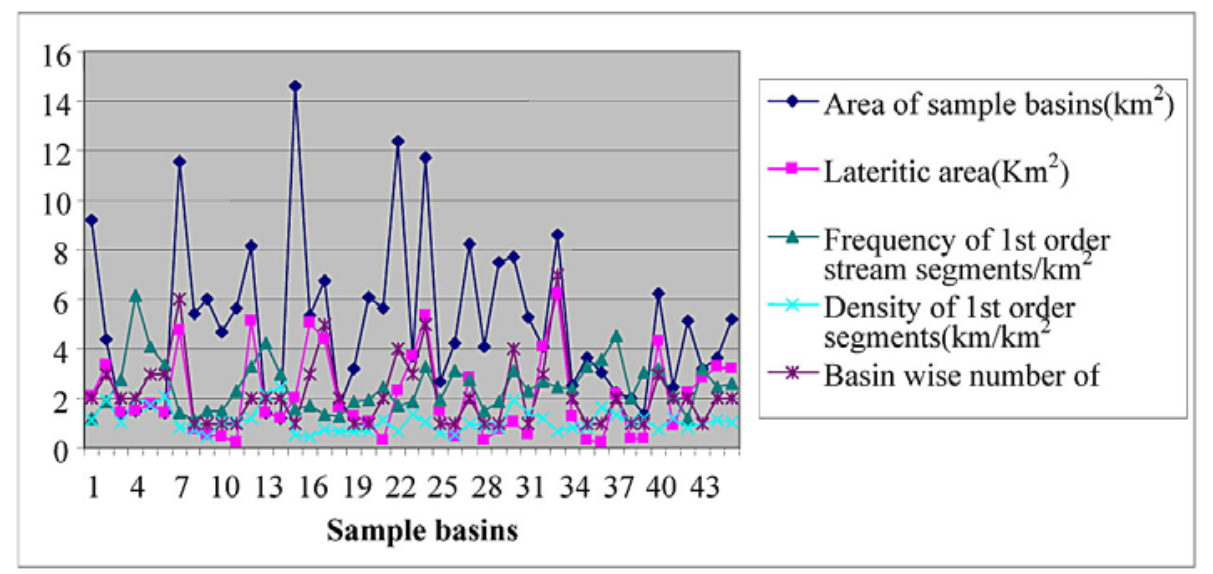

FIGURE 5. First order drainage characteristics of sample basins.

\subsection{Characteristics of sample basins with rills indu- ced lateritic confinement (devoid of significant gully}

Majority of the sample basins (27 in number out of the total 45) are more susceptible to the process of rilling than significant gullying. The lateritic coverage in these basins varies between $0.23 \mathrm{~km}^{2}$ and $6.22 \mathrm{~km}^{2}$ .It is insignificant (below $\left.1 \mathrm{~km}^{2}\right)$ in 8 basins $(7,8,10$, 29, 35 and others). Most of the basins susceptible to this processes in their lateritic enclosures are frequent on the granite-gneissic- gently undulating plain across the rainfall regime of $1400 \mathrm{~mm}$ and rainfall intensity of more than 100 (Fournier index) lying in the western Dubrajpur, Khayrasol, Md Bazar and Rajnagar blocks (FIG 3, 6, 10 \& 13). On average, these basins are characterised by low magnitude of relative relief (1.82 $\left./ 100 \mathrm{~m}^{2}-2.2 / 100 \mathrm{~m}^{2}\right)$, dissection index $\left(0.01 / 100 \mathrm{~m}^{2}-\right.$ $\left.0.02 / 100 \mathrm{~m}^{2}\right)$, gently undulating slope $\left(1.62 \% / 100 \mathrm{~m}^{2}-\right.$ $3.83 \% / 100 \mathrm{~m}^{2}$ ), poor -moderate drainage frequency $\left(1.65 / \mathrm{km}^{2}-4.2 \mathrm{~km}^{2} ; 1^{\text {st }}\right.$ order $1.1 / \mathrm{km}^{2}-4.52 / \mathrm{km}^{2} ; 2.13 /$ $\left.100 \mathrm{~m}^{2}-4.01 / 100 \mathrm{~m}^{2}\right)$, coarse -moderate density $(1.34$ km²-3.23km/ km²;0.46km/ km²-1.96km/ km²;0.48m/ $\left.100 \mathrm{~m}^{2}-2.16 \mathrm{~m} / 100 \mathrm{~m}^{2}\right)$, moderate bifurcation ratio (2.04.6), elongation ratio (0.65-0.90) and very low relief ratio. All these morphometric magnitudes (FIG 7 and TAB. 5) and dominance of sandy loam texture with its moderate erodibility and low relief ratio motivate mostly moderate annual soil loss (12.45-23.13t/ha) and moderate state of erosion as shown in TAB. 3, 5 \& and FIG. $8 \& 12$. On average these basins are relatively larger in size and more elongated in shape than basins in lateritic patches in proximity to older and younger alluvium geomorphic units. Basins 16, 17 and 19 maintain their moderate erodibity inspite of the considerable depletion of protected forest and frequent existence of barren and scrubby patches in lateritic enclosure (Plate 1). It indicates prevalence of considerable infiltration capacity, permeability and limited 
runoff yield as reflected in their coarse-moderate morphometric magnitude of relief and drainage attributes and elongated shape and light texture-sandy loamy soil of lateritic profile. Consequently most of these basin experience moderate soil loss or moderate state of erosion (FIG. 7). The linear relation between soil erodibility, drainage density and mean annual precipitation - rainfall erosivity on laterite are $0.51,0.42$ and 0.53 respectively. Rill induced lateritic surfaces in 27 basins varies between $4.04 \%$ and $97.73 \%$ out of the total area of the basins. Few basins (7, 8, 9, 10, 11
\& 45) register low rill erosion having mean annual soil loss below 12t/ha. Hence It can be said that basin with significant lateric exposures, high rainfall and the heavier soil texture (clay/clay loam) are more susceptible to the rills and gullies than those basins with the relatively smaller extent of laterites, less mean annual rainfall and lighter soil texture-sandy loam. Basin with considerable rills but insignifican gullies attain mostly moderate state of erosion. Maximum number of rill and gully effected lateritic villages are located in the basin 12.

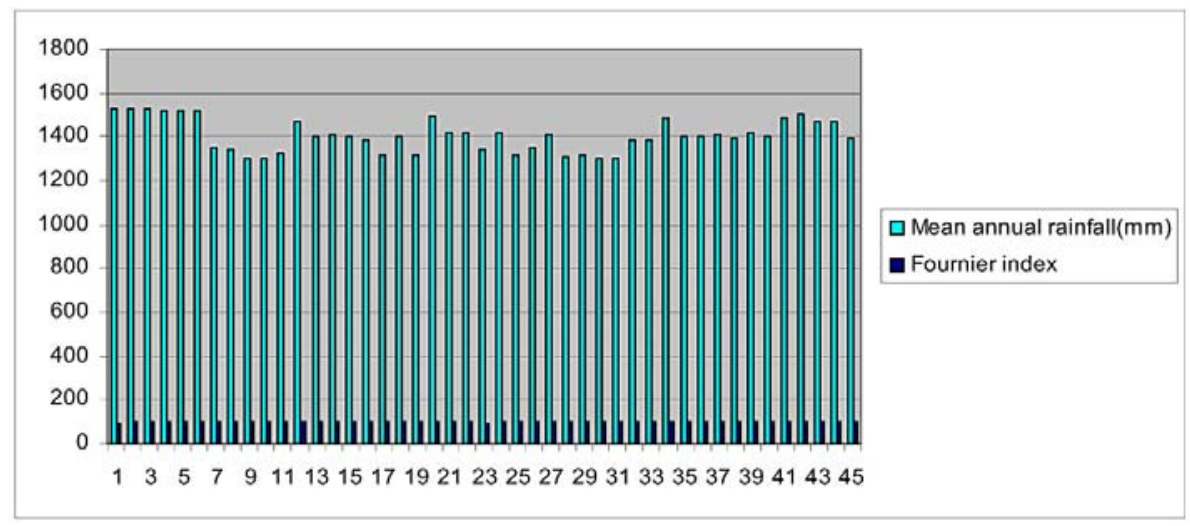

FIGURE 6. Rainfall (mm) characteristics for the period between 1999-2007.

TABLE 2. Geomorphometric characteristics of sample drainage basins having signinificant extent of rill-gully affected lateritic exposures.

\begin{tabular}{|c|c|c|c|c|c|c|}
\hline & \multicolumn{5}{|c|}{ Magnitudes of morphometric attributes laterite coverage } & \multirow[b]{2}{*}{ Dominance } \\
\hline & $\begin{array}{c}\text { Range of } \\
\text { obtained values }\end{array}$ & Dominance & $\begin{array}{c}\text { Range of } \\
\text { obtained values }\end{array}$ & Dominance & $\begin{array}{c}\text { Range of } \\
\text { obtained values }\end{array}$ & \\
\hline $\begin{array}{l}\text { Lateritic } \\
\text { Coverage(\%) }\end{array}$ & $<40(10.24-35.51)$ & Small & 40-80(45.19-77.41) & Moderate & $>80(86.60-100.0)$ & High \\
\hline Basin Number & $1,15,24,41$ & & $2,12,20,42$ & & $3,4,5,6,13,14,18,32,43,44$ & \\
\hline Basin order & III & & II(1in number)III & & II(2in number) \& III & \\
\hline Basin area $\left(\mathrm{Km}^{2}\right)$ & $2.45-14.61$ & Small & $4.34-8.14$ & Moderate & $1.21-5.2$ & Very small \\
\hline $\begin{array}{l}\text { Weighted Mean of } \\
\text { bifurcation ratio }\end{array}$ & $2.03-3.78$ & Moderate & $2.53-3.56$ & Moderate & $2.0-4.34$ & Moderate \\
\hline $\begin{array}{l}\text { Mean length(km) of } \\
1^{\text {st }} \text { order segments }\end{array}$ & $0.50-0.80$ & Low & $0.58-.0 .73$ & Low & $0.38-0.45$ & Low \\
\hline $\begin{array}{l}\text { Drainage frequency } / \mathbf{K m}^{2} \\
\text { of } \mathbf{1}^{\text {st }} \text { order segments }\end{array}$ & $1.17-3.26$ & coarse & $1.18-3.84$ & Coarse & $2.30-6.16$ & Moderately fine \\
\hline $\begin{array}{l}\text { Drainage densityKm/Km² } \\
\text { of } 1^{\text {st }} \text { order segments }\end{array}$ & $0.52-1.22$ & Coarse & $0.68-1.94$ & Coarse & $0.94-2.47$ & Moderate \\
\hline $\begin{array}{l}\text { Drainage } \\
\text { frequency/Km}{ }^{2}\end{array}$ & $1.62-2.45$ & Poor & $2.61-4.92$ & Moderate & $2.0-8.21$ & Moderately fine \\
\hline Drainage density $\mathbf{K m} / \mathbf{K m}^{2}$ & $1.33-2.04$ & Coarse & $1.56-2.22$ & coarse & $1.42-2.94$ & Moderate \\
\hline Elongation ratio & $0.7-0.92$ & Less elongated & $0.74-0.86$ & Oval & $0.73-0.92$ & Oval \\
\hline Relief ratio & $0.01-02$ & Low & $0.02-0.03$ & Low & $0.01-0.03$ & Low \\
\hline
\end{tabular}


Rill and gully erosion risk of lateritic terrain in South-Western Birbhum District, West Bengal, India V. C. Jha, S. Kapat

TABLE 3. Geomorphometric characteristic of sample drainage basins having rills induced lateritic surface (devoid of significant gullies).

\begin{tabular}{|c|c|c|c|c|c|c|}
\hline & \multicolumn{5}{|c|}{ Magnitudes of morphometric attributes laterite coverage } & \multirow[b]{2}{*}{ Dominance } \\
\hline & $\begin{array}{c}\text { Range of } \\
\text { values }\end{array}$ & Dominance & $\begin{array}{l}\text { Range of } \\
\text { values }\end{array}$ & Dominance & $\begin{array}{c}\text { Range of } \\
\text { values }\end{array}$ & \\
\hline $\begin{array}{l}\text { Lateritic } \\
\text { Coverage(\%) }\end{array}$ & $<20(4.04-19.79)$ & Insignificant & $20-40(30.76-39.37)$ & Small & $>40(41.31-97.73)$ & Moderate \\
\hline \multirow[t]{2}{*}{ Basin Number } & 8,9,10,11,21,22,26, & $39,19,27$ & Small & $7,16,17,23,25$ & & \\
\hline & 28,29,30,31,35,36,38 & & & $33,34,37,40,45$ & & \\
\hline Basin order & III & & III & & III & \\
\hline Basin area $\left(\mathrm{Km}^{2}\right)$ & $1.97-12.43$ & Large & $1.3-8.23$ & Moderate & $2.21-11.52$ & Moderate \\
\hline Mean bifurcation ratio & $2.0-4.6$ & Moderate & $2.35-4.01$ & Moderate & $1.98-4.34$ & Moderate \\
\hline $\begin{array}{l}\text { Mean length }(\mathrm{km}) \text { of } \\
1^{\text {st }} \text { order segments }\end{array}$ & $0.16-0.63$ & Low & $0.30-0.71$ & Low & $0.37-0.81$ & Low \\
\hline $\begin{array}{l}\text { Drainage frequency/Km² } \\
\text { of } \mathbf{1}^{\text {st }} \text { order segments }\end{array}$ & $1.1-3.58$ & Coarse & $1.87-3.04$ & Coarse & $1.34-4.52$ & Moderate \\
\hline $\begin{array}{l}\text { Drainage densityKm/Km² } \\
\text { of } \mathbf{1}^{\text {st }} \text { order segments }\end{array}$ & $0.48-1.43$ & Coarse & $0.65-1.21$ & Coarse & $0.46-1.35$ & Coarse \\
\hline Drainage frequency $/ \mathrm{Km}^{2}$ & $1.65-4.2$ & Moderate & $2.81-2.45$ & Moderate & $1.40-3.88$ & Moderate \\
\hline Drainage densityKm/Km² & $1.03-3.25$ & Coarse & $2.0-2.53$ & Coarse & $1.34-2.17$ & coarse \\
\hline Elongation ratio & $0.70-0.92$ & Elongated & $0.70-0.81$ & Less elongated & $0.65-.92$ & Elongated \\
\hline Relief ratio & $0.10-0.30$ & Low & $0.026-0.032$ & Low & $0.029-0.033$ & Low \\
\hline
\end{tabular}

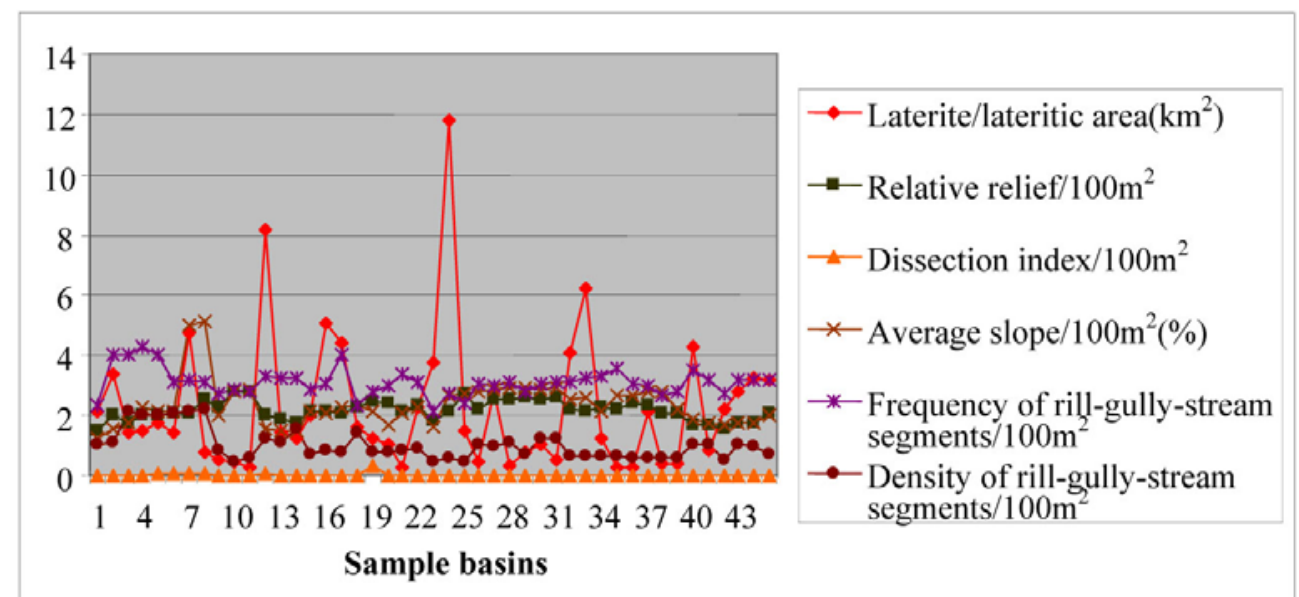

FIGURE 7. Morphometric magnitudes of rill gully affected lateritic patches within sample basins 
TABLE 4. Chracteristics of rill and gully induced lateritic surface in sample basins

\begin{tabular}{|c|c|c|c|c|c|c|}
\hline & \multicolumn{6}{|c|}{$\begin{array}{l}\text { Magnitudes of morphometric attributes in combination with soil texture,soil erodibility, } \\
\text { soil loss, extent of rill\& gully aff ected area }\end{array}$} \\
\hline & Range of values & Dominance & Range of values & Dominance & Range of values & Dominance \\
\hline $\begin{array}{l}\text { Lateritic coverage } \\
\left(\% \& \mathrm{Km}^{2}\right)\end{array}$ & $<40(10.24-35.51)$ & & $40-80(45.19-77.41)$ & & $>80(86.60-100.0)$ & \\
\hline Basin number \& order & $1,15,24,41$ & III rd order & $2,12,20,42$ & III rd order & $3,4,5,6,13,14,18,32,43,44$ & III rd order \\
\hline Mean Relative relief/m² & $1.52-2.16$ & Low & $1.53-2.42$ & Low & $1.73-2.24$ & Low \\
\hline MeanDissection index $/ \mathrm{m}^{2}$ & $0.01-0.02$ & Low & $0.015-0.038$ & Low & $0.026-0.034$ & Low \\
\hline Average slope/ m²(\%) & $1.23-2.13$ & Level & $1.70-1.58$ & level & $1.73-2.03$ & Very Gentle \\
\hline $\begin{array}{l}\text { Mean drainage } \\
\text { (rill-gully-stream) } \\
\text { frequency/ m² }\end{array}$ & 2.32-3.17 & Moderate & $2.70-4.31$ & Moderately fine & $3.01-4.41$ & Moderately fine \\
\hline $\begin{array}{l}\text { Mean drainage } \\
\text { (rill-gully-stream) } \\
\text { density } \mathbf{m} / \mathbf{m}^{2}\end{array}$ & $0.58-1.02$ & Moderate & $0.53-2.11$ & Moderate & $2.34-2.49$ & Moderate \\
\hline MeanAnnual rainfall(mm) & 1402.23-1529.44 & ModeratelyHigh & 1405.24-1528.69 & High & 1384.59-1529..61 & Very high \\
\hline Fournier Index & $90.41-101.64$ & High & $99.16-100.62$ & & $97.23-100.44$ & \\
\hline Soil texture & $\begin{array}{l}\text { Clay loam - } \\
\text { Sandy loam }\end{array}$ & \begin{tabular}{|c|} 
Clay loam \\
(relatively heavier \\
texture)
\end{tabular} & $\begin{array}{l}\text { Clay-Clay loam- } \\
\text { sandy clay loam }\end{array}$ & \begin{tabular}{|c|} 
Clay loam \\
(relatively heavier \\
texture)
\end{tabular} & $\begin{array}{l}\text { Clay-Clay loam- } \\
\text { sandy clay loam }\end{array}$ & $\begin{array}{c}\text { Clay loam } \\
\text { (relatively heavier } \\
\text { texture) }\end{array}$ \\
\hline Mean Soil erodibility & $0.25-0.3$ & Moderate & $0.27-0.45$ & High & $0.29-0.42$ & High \\
\hline $\begin{array}{l}\text { Mean annual Soil loss } \\
\text { (t/ha) }\end{array}$ & $11.42-23.77$ & Moderate & $16.21-25.19$ & High & $14.11-28.23$ & High \\
\hline $\begin{array}{l}\text { Rill \& gully affected non } \\
\left.\text { arable area( } \mathrm{Km}^{2}\right)\end{array}$ & $0.64-3.51$ & Moderate & $1.01-2.36$ & High & $0.40-1.80$ & High \\
\hline
\end{tabular}

TABLE 5. Characteristics of rill induced lateritic surface in sample basins (devoid of significant gullies)

\begin{tabular}{|c|c|c|c|c|c|c|}
\hline & \multicolumn{6}{|c|}{$\begin{array}{l}\text { Magnitudes of morphometric attributes with laterite coverage, } \\
\text { soil texture, soil erodibility, soil loss, extent of rills affected area }\end{array}$} \\
\hline & Range of values & Dominance & Range of values & Dominance & Range of values & Dominance \\
\hline $\begin{array}{l}\text { Lateritic } \\
\text { coverage }\left(\% \& \mathrm{Km}^{2}\right)\end{array}$ & $<40(4.04-19.79)$ & & $40-80(30.76-39.37)$ & & $>80(41.31-97.73)$ & \\
\hline $\begin{array}{l}\text { Basin number } \\
\text { \& order }\end{array}$ & $\begin{array}{c}\text { 8,9,10,11,21,22,26, } \\
28,29,30,31,35,36,38\end{array}$ & III rd order & $39,19,27$ & III order & $\begin{array}{c}\text { 7,16,17,18,23,25 } \\
33,34,37,40,45\end{array}$ & III rd order \\
\hline Mean Relative relief/m² & $2.08-2.17$ & Low & $2.07-2.50$ & Low & $1.82-2.06$ & Low \\
\hline Mean Dissection index $/ \mathrm{m}^{2}$ & $0.02-0.037$ & Low & $0.02-0.03$ & Low & $0.01-0.035$ & Low \\
\hline Average slope/ m²(\%) & $2.09-4.83$ & Gently undulating & $2.11-2.87$ & Gentle & $1.62-4.80$ & Gentle \\
\hline $\begin{array}{l}\text { Mean drainage (rill-gully- } \\
\text { stream) frequency/ } \mathbf{m}^{2}\end{array}$ & $2.13-3.87$ & Moderate & $2.63-3.0$ & Moderate & $3.07-4.01$ & Moderate \\
\hline $\begin{array}{l}\text { Mean drainage (rill-gully- } \\
\text { stream) density } \mathbf{m} / \mathbf{m}^{2}\end{array}$ & $0.57-2.21$ & Moderate & $0.56-1.0$ & Moderate & $2.16-2.16$ & Moderate \\
\hline $\begin{array}{l}\text { MeanAnnual } \\
\text { rainfall(mm) }\end{array}$ & 1298.67-1489.82 & Moderate & 1317.08-1423.44 & Moderate & 1320.31-1499.02 & Moderate \\
\hline Fournier Indax) & 98.48-102.52 & High & $100.23-103.16$ & High & $95.64-102.72$ & high \\
\hline Soil texture & $\begin{array}{l}\text { Sandy loam- } \\
\text { Sandy clay loam- } \\
\text { gravelly loam }\end{array}$ & $\begin{array}{l}\text { Sandy loam } \\
\text { (light texture) }\end{array}$ & $\begin{array}{l}\text { Sandy loam- } \\
\text { gravelly loam }\end{array}$ & $\begin{array}{c}\text { Sandy loam } \\
\text { (light texture) }\end{array}$ & $\begin{array}{l}\text { Sandy loam- } \\
\text { Sandy clay loam, } \\
\text {-Gravelly loam }\end{array}$ & $\begin{array}{c}\text { Sandy loam } \\
\text { (Light texture) }\end{array}$ \\
\hline Soil erodibility & $0.17-0.38$ & Moderate & $0.19-0.33$ & Moderate & $0.18-0.37$ & Moderate \\
\hline $\begin{array}{l}\text { Mean annual Soil } \\
\operatorname{loss(t/ha)}\end{array}$ & $10.23-23.34$ & Moderate & $7.31-14.13$ & Moderate & $11.35-23.77$ & Moderate \\
\hline $\begin{array}{l}\text { Rill (along with insignificant } \\
\text { /small gullies) affected non } \\
\text { arable area(Km²) }\end{array}$ & $0.23-1.68$ & Moderate & $0.4-2.33$ & Moderate & $1.0-2.79$ & \\
\hline
\end{tabular}




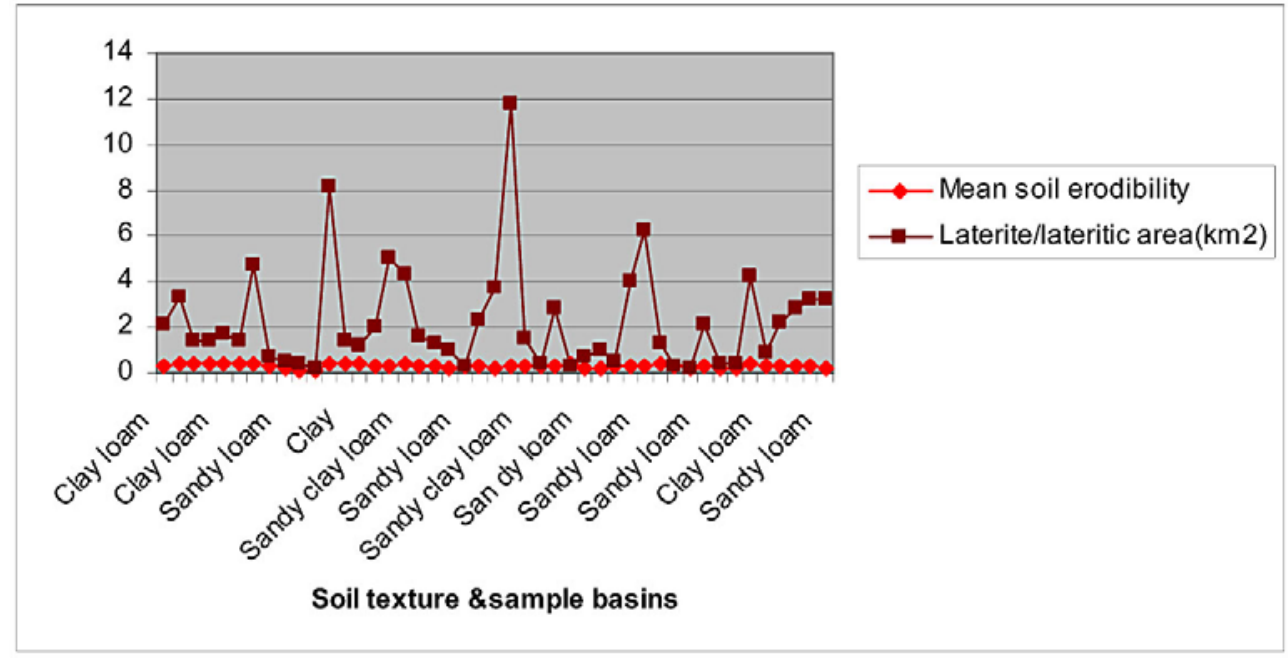

FIGURE 8. Soil texture and soil erodibility of lateritic surfaces in sample basins.

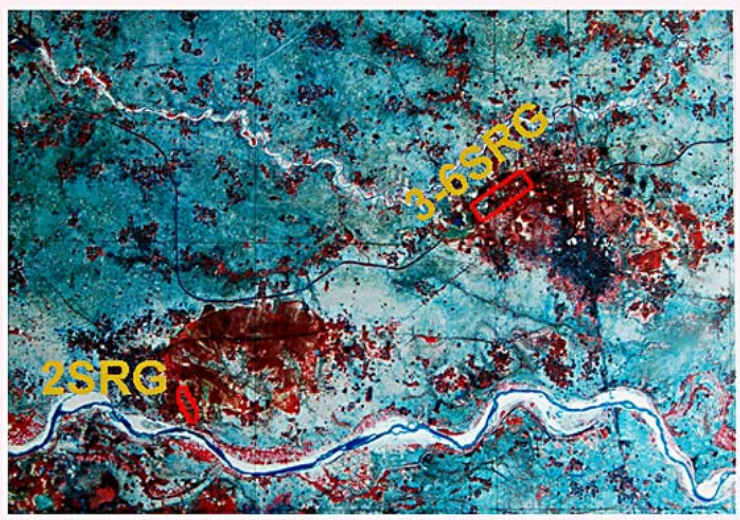

Plate:Satellite Imagery(Precision Geocoaded P6\&LISSIII,No73M/10,2006)Showing Severely Rill and Gully Affected Basins (2-6 SRG)

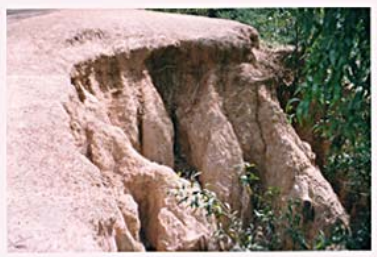

Plate:Flutted Gully wall

In the Basin- 4

(Bolpur-Sriniketan

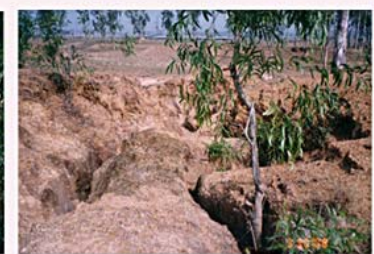

Plate:Severely rill-

Gully affected Lateritic Landscape as noted

Block at Kabimahanpur) in the Basin-4

(Bolpur-Sriniketan

Block at Ballavpur)

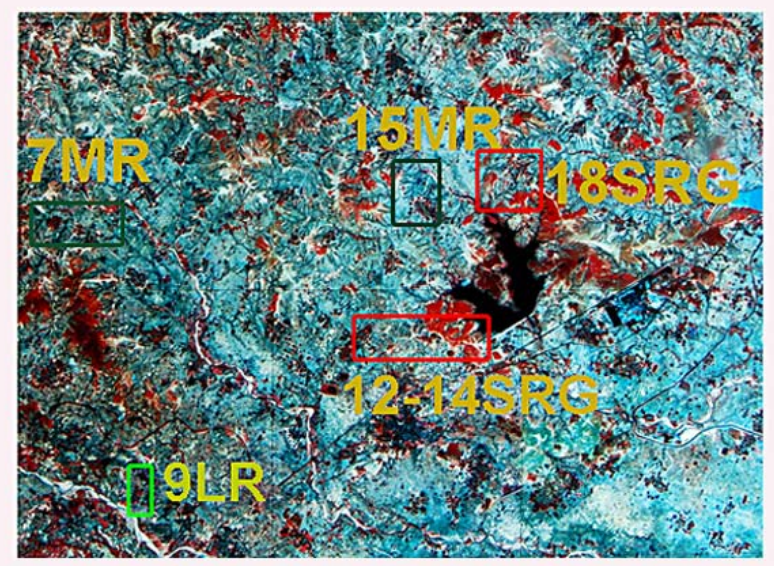

Plate: Satellite Imagery(Precision Geocoded P6 and LISS III 2006,No73M/5)showing Rill-tGully Induced Lateritic Landscape as noted in the basins-9(Least 'LR'),7\&15(Moderate'MR') and 12-14\&18 (Severe'SRG').

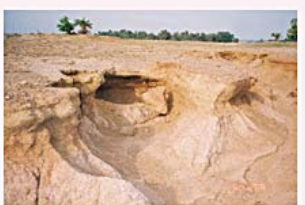

Plate:Severe rill \& Gully erosion in the Basin-13 in Dubrajpur Block

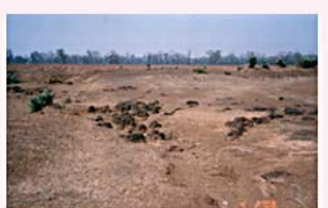

Plate:Moderate rill erosion in the basin -15 in Dubrajpur Block
FIGURE 9. Severaly gully erosion risk 
TABLE 6. Temporal changes in the largest gullyand its sub gullies confined to Ballavpur lateritic patch.

\begin{tabular}{|c|c|c|c|c|c|c|c|c|c|}
\hline \multirow[b]{2}{*}{ Location } & \multicolumn{4}{|c|}{ Depth of main gully(m) } & \multicolumn{4}{|c|}{ Width of main gully(m) } & \multirow{4}{*}{$\begin{array}{l}\text { Morphological andmorphometric } \\
\text { Characteristics } \\
\text { • maximum relative relief } 4.23 \mathrm{~m} / 100 \mathrm{~m} \\
\text { - max-dissection index }-0.06 / 100 \mathrm{~m}, \\
\text { • max drainage (rill, gully \&stream) density } 3.2 \mathrm{~m} / 100 \mathrm{~m}^{2} \text {, } \\
\text { • max drainage (rill-gully-stream) frequency } / 100 \mathrm{~m}^{2}, \\
\text { - elongation ratio-0.92, }\end{array}$} \\
\hline & 1986 & 1996 & 2003 & 2008 & 1986 & 1996 & 2003 & 2008 & \\
\hline $\begin{array}{l}\text { Near source } \\
\text { of gully }\end{array}$ & 7.60 & 9.10 & 9.80 & 9.93 & 25.3 & 31.70 & 37.80 & 37.87 & \\
\hline $\begin{array}{l}\text { Near mouth } \\
\text { of gully }\end{array}$ & 6.00 & 6.70 & 7.0 & 7.22 & 43.50 & 46.80 & 49.60 & 49.82 & \\
\hline \multirow[t]{2}{*}{ Location } & \multicolumn{4}{|c|}{$\begin{array}{l}\text { Depth of sub gully developed } \\
\text { on the left bank of the main } \\
\text { gully near source }\end{array}$} & \multicolumn{4}{|c|}{$\begin{array}{l}\text { Width of sub gully developed } \\
\text { on the left bank of the main } \\
\text { gully near source }\end{array}$} & $\begin{array}{l}\text { - Proceses-fluting, wall failure, circular slip, basal slip, } \\
\text { caving/piping, scouring etc } \\
\text { • land forms-collapse features, haystack mound, tunnel, }\end{array}$ \\
\hline & 1986 & 1996 & 2003 & 2008 & 1986 & 1996 & 2003 & 2008 & \\
\hline $\begin{array}{l}\text { Near source } \\
\text { of gully }\end{array}$ & 2.50 & 5.80 & 8.75 & 8.87 & 0.85 & 1.40 & 1.88 & 2.03 & \\
\hline $\begin{array}{l}\text { Near mouth } \\
\text { of gully }\end{array}$ & 2.00 & 5.20 & 9.68 & 9.72 & 1.15 & 1.80 & 2.25 & 2.36 & \\
\hline
\end{tabular}

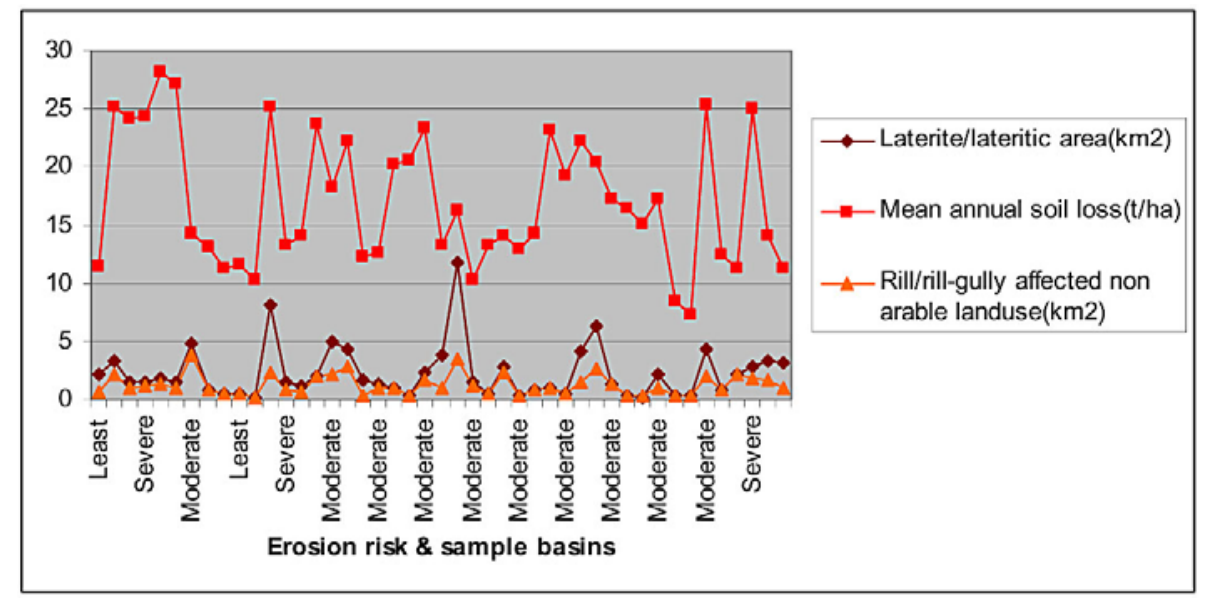

FIGURE 11. Erosion risk, annual top soil loss and rill and gully affected lateritic surfaces in sample basins.

\subsection{Risk of Rill and Gully erosion}

According to the forgoing analysis, current status of rill and gully erosion of sample basins can be classified into three categories like least, moderate and severe erosion risks reflecting varying type, extent, potentialities and limitations (FIG 10, 11,12 \& 13) as given below.

Least rill and gully erosion risk: 8 sample basins covering 11 villages belong to this category having lateritic coverage between $0.23 \mathrm{~km}^{2}$ and $3.20 \mathrm{~km}^{2}$ basin area between $1.02 \mathrm{~km}^{2}$ and $9.22 \mathrm{~km}^{2}$. They are characterized by stable terrain with least mean annual soil loss t/ha between7.39 and 11.97, least area affected (non agricultural land) between $4.04 \mathrm{~km}^{2}$ and 19.61 $\mathrm{km}^{2}$ and least terrain deformations. FIG. 13 resembles their existence both over level and gentle slope from east to west. Least risk of lateritic exposures coincides with low morphometric magnitude (either per $\mathrm{km}^{2}$ or $100 \mathrm{~m}^{2}$ ), mean annual rainfall between $1300 \mathrm{~mm}$ 1550mm,Fournier index between 99 and 103.22 and soil erodibility between $0.18-0.26$ (FIG 9-13). Lateritic exposures of these basins have least limitation for land use. Their geomorphic priority is low as lateritic landscape under this category is economically viable 
and even can be used for agricultural purpose ofcourse other than paddy cultivation.

Moderate rill and gully erosion risk: Majority of sample basins (26 in number) occupying 59 affected villages attain moderate risk. Their basin area and lateritic coverage vary between $2.21 \mathrm{~km}^{2} \& 14.61 \mathrm{~km}^{2}$ and $14.615 .13 \%$ \& $97.73 \%$ respectively. Basins under moderate risk are usually subjected to the process of rilling .In these cases, the process of gullying is insignificant. They are characterized by moderate morphometric magnitude to some extent , sandy loam soil texture, mean annual soil loss between $12.43 \mathrm{t} / \mathrm{ha}$ \&23.13 t/ha ,area under combinations of rills and rills with insignificant gullies - between 5.13\% \& 48.41\% and least to moderate terrain deformations. Some of these basins like 16, 17, 19 etc are evidenced by human induced alteration of lateritic topography by clearing protected forest, extracting morram from lateritic profile etc. Such erosion risk is mostly prevalent nearly across mean annual rainfall regime of $1450 \mathrm{~mm}-\& 1500 \mathrm{~mm}$ and Fournier index of 99 . These basins have moderate priority and limitations for their rehabilitation and landuse. Economic viability of these basins can be increased by moderate leveling of rills and small insignificant gullies, social and agro forestry on barren surfaces and revegetation of depleting forest considerable area can be brought under the dry farming after the moderate reclamations.
Severe rill and gully erosion risk: 11 out of 45 sample basins are characterized by severe rill and gully erosion .It includes 27 villages. This risk is prevalent in the sample basins lying on the right bank of the kopai and Bakreswar nadi, left bank the Ajay and Mayurakshi rivers in Bolpur-Sriniketan, Dubrajpur and MD.Bazar block. Of course these basins are very small in size $\left(1.21 \mathrm{~km}^{2}-4.34 \mathrm{~km}^{2}\right)$ and less elongated or circular in shape.They have appreciable extent of lateritic exposures(63.14\%-100.0\%). Particularly sample basins 3-6 in the Kopai catchment attain spectacular dimention of severity affecting $24.55 \%-76.42 \%$ of the area. Basin-4 have only the largest gully acquiring the highest geomorphic magnitude in all respects (TAB. 6, FIG. 9,10.). Sample basins of high severity are characterized by severe mean annual soil loss (24.00$28.23 \mathrm{t} / \mathrm{ha}$ ) and strong terrain deformations corresponding to high mean annual rainfall(mm), higher soil erodibility with clay - clay loam texture.These basins are actually the reflection of accelerated soil erosion. Infact, inherent fragilility of lateritic landscape and adverse impact of degradation of forest, irrigation canal, urbanization, morrum and china clay mining make them more severe in character. They are prone to the backflow from nearby river in rainy season. These basins have high priority for reclamation in view of severe terrain limitations. These basins can be managed by taking initiatives for horticulture, social forestry and tourism.

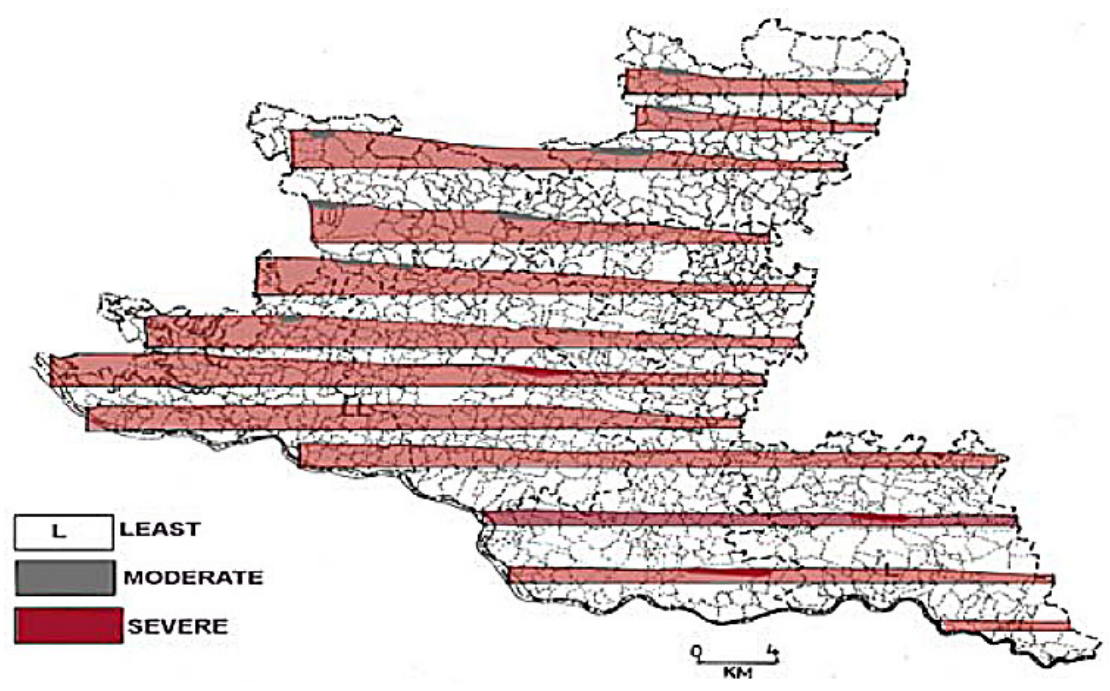

FIGURE 12. Landscape Profiles and Lateritic Surface Under Varying Severity of Rills and Gullies in Sample Basins. 


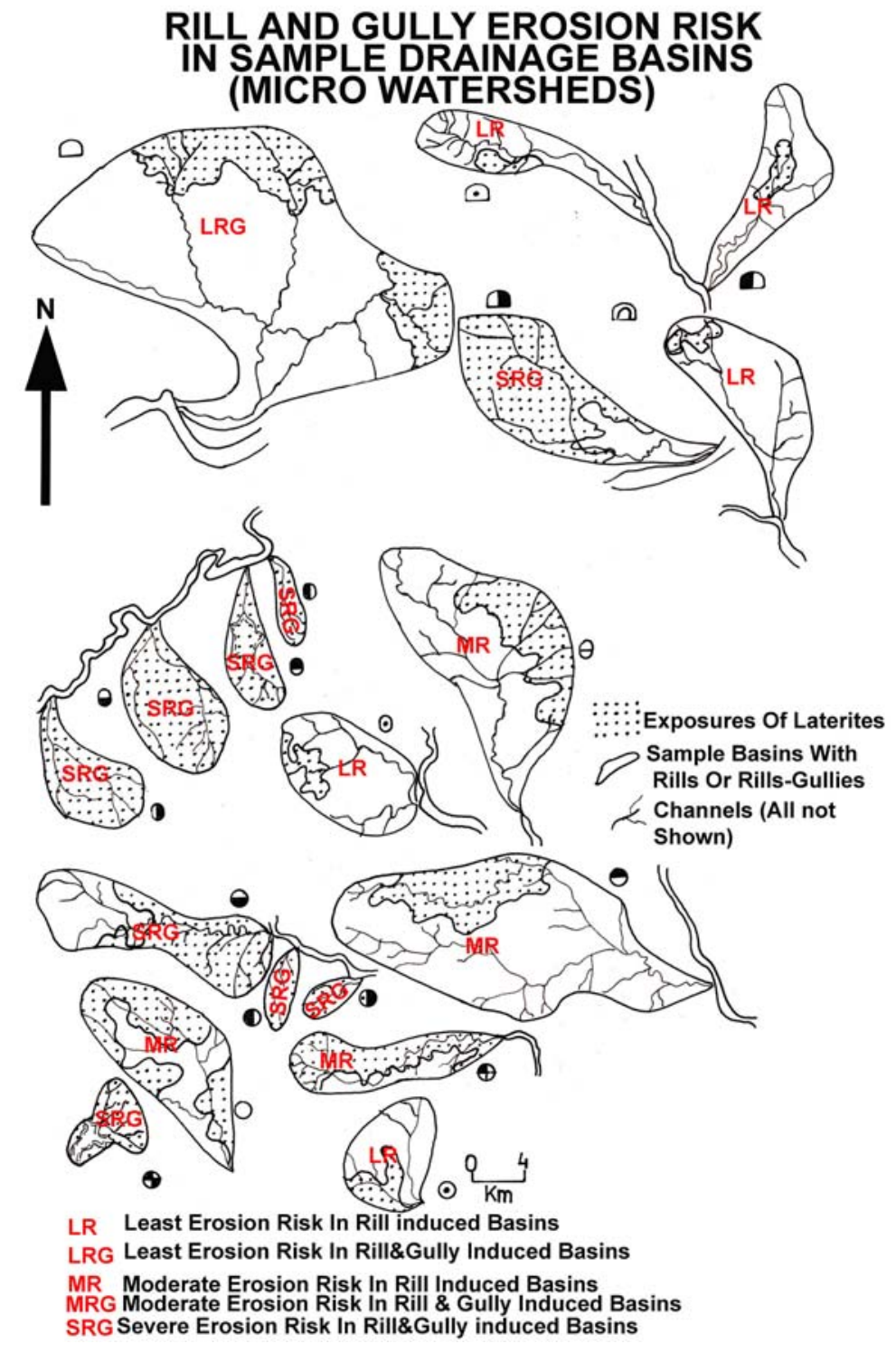

FIGURE 13. Riil and Gully Erosion Risk in Sample Drainage Basins.

Hence from above discussion it is clear that significant extent of laterite exposures, mean annual rainfall,drainage morphometric magnitude, soil erodibility, top soil loss, susceptibility to rill and gully erosion are directly related. Inherent characteristics of lateritic landscape coupled with human intervention are responsible for varying degree of rill and gully erosion risk. Moderate erosion risk dominates the study area and it is mainly related to the lateritic landscape affected by rill erosion. On the contrary basins with both rills and gully networks have severe erosion risk.

\section{ACKNOWLEDGEMENTS}

Authors are grateful to the Department of Science and Technology, Government of West Bengal, India for funding this research and development project.

\section{REFERENCES}

BISWAS, A. Laterites and Lateritoids of Rahr Bengal. In DATYE, V. S. et al (Ed). Explorations in the Tropics. Prof. K. D. Dikshit Felicitation Volume 
Rill and gully erosion risk of lateritic terrain in South-Western Birbhum District, West Bengal, India

V. C. Jha, S. Kapat

Committee, 1987. p. 48 - 54.

BUCHANAN, F. A journey from Madras through the countries of Mysore,Canara and Malbar - East India Co, London ,v. 2, 1807, p 440 - 441.

CHANDRA, S. K. Efficient Management of Land Resources for Sustainable Agriculture in Bihar. Journal of the Indian Society of Soil Science, v. 54, n.4, 2006. p $435-442$.

CHORLEY ,R.J. Drainage Basin as the Fundamental Geomorphic Units. In: CHORLEY, R. J. (Ed). Water, Earth and Man. Methuen Co Ltd, 1969. p.77 - 99.

COATES , D. R. Quantitative Geomorphology of Small Drainage Basins of Southern Indiana. Department of geology, Columbia University, Technical Report 10. 1958.

CHAUDHARY, R. S.; SHARMA,P.D. Erosion Hazard Assessment and Treatment Prioritization of Giri river Catchment, Nort western Himalayas. Indian Journal of soil conservation, 26(1), 1998. p. 6 - 11.

Chakrabarti, A. K. Sediment Yield Prediction and Prioritization of Watersheds using Remote Sensing Data, Proceedings of 12th ASIAN CONFERENCE ON REMOTE ENSING,Singapur, 1991. p.q-3-1toq3-6.

DOV NIR. The Ratio of Relative and Absolute Altitudes of Mt. Carmel, a Contribution to the Problem of Relief Analysis and Relief Classification. Geographical Review, USA, v. 47, 1957. p.564 - 569.

DURBUDA, D. G. et al. Estimation Surface Runoff Potential of a Watershed in Semi arid Environment A case study. Journal of Indian society of remote sensing, 31(1), 2001. p. $11-18$.

HORTON, R. E. Drainage Basin Characteristics. Trans. Am. Geophys Union, 13, 1932. p. 350 - 361.

HORTON, R. E. Erosional Development of Streams and Their Drainage Basins: Hydrological Approach to
Quantitative Morphology. Bull. Geol. Soc. Am, v.56, 1945. p. $270-275$.

JHA, V. C. Wasteland Types and their Effective Utilization in Birbhum District, The Deccan geographer, Vol.25, 2 \&3, 1987. p. 231 - 422.

JHA, V. C. Himalayan Geomorphology. Rawat publishing Co, Jaipur and New Delhi, 1996. p.112 - 144.

JHA, V. C. Laterite and landscape development in tropical lands,a case study. In: NAG, P.; KUMRA, V.; SINGH, J. (Ed). Geography and Environment, Concept, 1997.

JHA, V. C. Denudational Processes and Land form Characteristics of Lateritic Terrain of Birbhum District, W.B, India. Transactions. Journal of the institute of Indian Geographers, v. 27, n.1, 2005. p. 19 - 29.

JHA, V.C. Land Degradation and Desertification and Integrated Management of Laterite Surface in Birbhum District Using Field and Remote Sensing Techniques, DST (W.B) sponsored project report, 2008. p.1-145.

JHA,V.C.; KAPAT, S. Gully erosion and its implications on land use ,a case study. In JHA, V.C. (Ed). Land degradation and desertification. Publ., Jaipur and New Delhi, 2003. p.156 - 178.

JASMIN, B.B; MARTIN,C. R. Mechanical Structure for Soil Erosion Control; Proceedings of a WORKSHOP ON SOIL EROSION MANAGEMENT, PCARRD, Los Banos, Philippine, 1984. p. 50 - 51.

JOSHI, V.; KALE ,V.S. The Contribution of Side Wall Erosion in Gully Development. Indian Geomorphology, Landform and processes, v.1, Rawat publication, Jaipur, 1995. p. 45.

MORISAWA, M. E. Relation of Quantitative Geomorphology to Stream Flow in Representative Watersheds of the Appalachian Plateau Province. Dept of Geology, Columbia University, Technical Report 20, 1959. 
MC FARLANCE , M. J. Geomorphological Analysis of Laterites and Its role in Prospecting. In: BANERJEE, P. K. (Ed). Laterization process. Geological Survey of India, v.120, 1986. p. $29-40$.

MILLAR, V. C. A Quantitative Geomorphic Study of Drainage Basin Characteristics. In: Clinch Mt. Area, Virginia and Tennessee,Tech.Rep. n. 3, Dept of Geogr. Col. Univ, New York, 1953.

MISRA, N. S. et al. Effect of Topo Elements on the Sediment Production Rate from Sub watersheds in the Upper Damodar Valley. Journal of Agricultural Engg (ISAE), 21(3), 1984. p. 65 - 70.

MUKHERJEE, S. K. Laterization Process, Geological Survey Of India, P.Banerjee ed., v. 120, 1986. p. $1-7$.

MULLER, J. E. An Introduction to the Hydraulic and Topographic Sinuosity Indices, AAAG, v.58, 1968. p. $371-385$.

MURTHY, K. S. R. Ground water Potential in a semi arid region of Andhra Pradesh, International Journal of the Indian society of remote sensing, 21(1), 2000. p. 11-18.

NIYOGI, P.; MALLICK, S. Quaternary Laterite of West Bengal,its Geomorphology Stratigraphy and Genesis. Q.J.Geol.Min.Metal Society. India, 45(4), 1973. p.155 - 174.

NOOKARATNAM, K. et al. Check Dam Positioning by Prioritization of Micro Watersheds. Jounal of the Indian Society of Remote sensing, v. 33, n. 1, 2005. p. $25-37$.

PATON, T. R.; WILLIAMS, M. A. J. The Concept of laterite. Annals of the Association of American Geographers, v.62, n.1, 1972. p. 42 - 56.

PENDLETON, R. L. et al. Laterite and Lateritic Soils. Common-Wealth Bureau of Soil Science Technical Communication.47, 1952. p.1-7.
SHARMA, H. S. Genesis of ravines of the lower Chambal Valley,India. Proceedings of $21^{\text {st }}$ INTERNATIONAL GEOGRAPHICAL UNION CONGRESS, INDIA, 1968. p.18-19.

SHARMA, H. S. The Physiography of the Lower Chambal Valley and its Agriculture Development: a study in Applied Geomorphology. Concept pub.Co, New Delhi, 1979.

SHARMA, H. S. Ravine Erosion in India. Concept pub Co, New Delhi, 1982.

SAXENA, R. K.et al. IRS-IC Data Application in Watershed Characterization and Management. International journal of Remote sensing, 21(17), 2000. p. 3197 - 3208.

SHEHGAL, J. Pedology, Concept and Applications. Kalyani Publishers, New Delhi, 1995. p. 82.

SMITH, G. H. The Relative Relief of Ohio. Geographical review, 25, 1935. p. $272-284$.

SINGH, K. D. Participatory of Watershed management -A Key to Sustainable Agriculture. Journal of the Indian Society of Soil Science, v.54, n.4, 2006. p. $443-451$.

SINGH, S.; DUBEY. Gully Erosion and Management, Method andApplications. New Academic Publisher, Delhi, 2002. p. 52 - 79.

SCHUMM, S. A. Evolution of Drainage Systems and Slopes in Badland at Perth Amboy, New Jersey, Bull.Geol.Soc.Am, v. 67, 1956. p. 597 - 646.

SINGH, S.et al. A Morphometric Study of Tributary Basins of the Upper Reaches of the Belan river. National Geographer, v.11, n.2, 1974. p. 123 - 131.

SINGH.S. et al. Geomorphological Evolution of Erosion surfaces of Belan Basin. National geographical Journal of India, v. 22, parts 3 and 4, 1976. p. $126-$ 138. 
SINGH, S. A Quantitative Analysis of Drainage Texture of Small Drainage Basins of Ranchi Plateau. Proceedings of SYMPOSIUM ON MORPHOLOGY AND EVOLUTION OF LANDFORMS, Dept of Geology, University of Delhi, 1978. p. 27 - 48.

STRAHLER, A. N. Dimentional Analysis in Geomorphology. Abstract, Bull geol Soc. Am, New York, v. 64,1953 . p. $1479-80$.

STRAHLER, A. N. Quantitative Analysis of Watershed Geomorphology, Transactions American geophysical union, v.38, n.6, 1958. p. 911 - 938.

STRAHLER, A. N. Quantitative Geomorphology of Drainage Basin and Channel Networks. In: CHOW, V.T. (Ed.) Handbook of Applied Hydrology, New York, Mc. Graw hill, 1964. p. 39 - 76.

TWIDALE, C. R. Sinkholes in Laterized Sediments ,Western Sturt plateau, Northern Territory of Australia. Geomorphology 1, Elsevier Science Publisher B.V, Amsterdam, 1987. p. 36 - 38.

VERMA, B. et al. Erosion studies of Mahi riverines in Gujarat, Indian Jr.Agricultural Sci., v. 39, 1969. p. $515-522$.

VOLKOFF, B. Red and Lateritic soils: World Scenario. In: SEHGAL, J.; BLUM, W. E. H.; GAJBHIYA, K. S. (Ed). Managing Red and lateritic soils for sustainable Agriculture. Oxford and IBH Publishing Co., New Delhi, v. 1, 1998. p. 57 - 74.

WISCHMEIER, W. H; SMITH, D. D. Predicting Rainfall Erosion Losses: A Guide to Conservation Planning. US Dept. of Agri. Hand book n.537, Washinton D.C. 1978. 